\title{
Leiomyoadenomatoid tumor of the uterus in pregnancy
}

\section{Gebelikte uterusun leiomyoadenomatoid tümörü}

\author{
Senem ERSAVAŞ ${ }^{1}$, Nuket ELIYYTKIN ${ }^{3}$, Sevil SAYHAN ${ }^{1}$, İsmail ZIHHNİ ${ }^{4}$, Çağlar SARIGÜL ${ }^{2}$, Ayşe YAĞCI ${ }^{2}$ \\ ${ }^{1}$ İzmir Tepecik Ĕ̆itim ve Araştırma Hastanesi, Tıbbi Patoloji Klini ği, İzmir \\ ${ }^{2} \dot{I} z$ mir Eğitim ve Araştırma Hastanesi, Tıbbi Patoloji Kliniği İzmir \\ ${ }^{3}$ Aydın Üniversitesi Tıp Fakültesi, Tıbbi Patoloji Anabilim Dalı, Aydın \\ ${ }^{4}$ Süleyman Demirel Üniversitesi Tıp Fakültesi, Genel Cerrahi Anabilim Dalı, Isparta
}

\begin{abstract}
Uterine adenomatoid tumors, in particular the intramural type is often accompanied by smooth muscle hypertrophy, which is usually represented by an entrapped myometrium permeated by the adjacent tumor. In some cases, the dominancy of smooth muscle component mimicks a leiomyoma, thus the lesion is denoted as a "leiomyoadenomatoid tumor". Indeed, the term "leimyoadenomatoid" is a descriptive name for this lesion and it reflects its histopathological appearance that is composed of prominently stromal smooth muscle cell proliferation accompanied by glandular structures. It is important that the surgeon and especially the pathologist recognize the existence of this tumor because its histological pattern is sometimes bizarre and the lesion could be misdiagnosed as a malignancy.

An uterine mass was detected in a 30 year-old woman during the fourth gestational month. Grossly, this white-coloured solid tumoral mass measuring $4.5 \times 4 \times 3 \mathrm{~cm}$ in size had a well circumscribed, smooth surface. The cut surface of specimen showed solid, grey-white mass with a whorled appearance.

During the microscopic examination of the mass, with a dominancy of fascicles of smooth muscle infiltrated by cuboidal to flattened and signet ring-like vacuolated epitheliallike cells, and tubuloglandular cystically dilated spaces were observed as well.

Tumors with a solid growth pattern or cords of cells can be mistaken for an infiltrating malignant epithelial or mesothelial neoplasm, or tumours with small vacuoles can be confused with a signet ring cell adenocarcinoma. Thus we herein report a rare case of uterine leiomyoadenomatoid tumor in a 30 year-old pregnant woman, and discussed its differential diagnosis and pathophysiology.
\end{abstract}

Key words: Leiomyoma, leiomyoadenomatoid tumor, pregnancy, progesterone

\section{ÖZET}

Uterin adenomatoid tumor, özellikle intramural tipte olmakla birlikte, komşu tümör alanlara yayılmış düz kas hipertrofisi şeklinde görülür. Bazı olgularda düz kasın baskınlı̆̆ı leimyomu taklit edebilir ve bu yüzden "leyomiyoadenomatoid tümör" olarak belirtilmiştir. Gerçekten de "leyomiyoadenomatoid tümör" terimi glandüler yapılarla baskın stromal düz kas proliferasyonu histopatolojik görünümü yansıtır. Tanının konması cerrah ve özellikle patolog açısından önemlidir. Çü̈nkü bazen hücreler bizar görünümlü olabilir ve malignteyle karışabilir.

Dört aylık hamile kadının uterusunda bir kitle saptandı. Makroskopik olarak 4,5x4x3 cm boyutlarında iyi sınırl, düzgün yüzeyli, sert beyaz bir kitle görünümdeydi. Kesit yüzeyi solid, gri beyaz ve hareliydi.

Mikroskopik olarak küboidal veya düzleşmiş ve taşlı yüzük hücreli vakuole epitelyal hücrelerle veya tübüler glandüler boşluklarla infiltre düz kas demetlerinden baskın bir kitle şeklindeydi.

Solid büyüme paterni veya hücre şeritleri şeklinde olabilen bu tümörler, infiltre malign epitelyal tümör veya mezotelyal neoplazm olarak veya küçük vakuollü hücreler, taşlı yüzük hücreli karsinom şeklinde yanlış tanı konabilir. Bu yüzden biz, 30 yaşında hamile bir kadının uterusunda gelişen leyomiyoadenomatoid tümör olgusunu sunduk ve ayırıcı tanı ve patofizyolojisini tartıştık.

Anahtar kelimeler: Leiomiyom, leiomiyoadenomatoid tümör, hamilelik, progesteron

Alındığı tarih: 01.03 .2015

Kabul tarihi: 16.03 .2015

Yazışma adresi: Ass. Senem Ersavaş, İzmir Tepecik Eğitim ve Araştırma Hastanesi, Tıbbi Patoloji Kliniği, 35000-İzmir e-mail: senemdeniz83@gmail.com 


\section{INTRODUCTION}

Adenomatoid tumors are relatively unusual benign solitary lesions that are mostly encountered in the genital tracts of both sexes including paratesticular structures in males and uterus, fallopian tubes, and ovaries in females ${ }^{(1,2)}$. Clinically, these lesions are usually found as incidental findings in $0.1-1 \%$ of females, in whom the uteri are removed for various other indications ${ }^{(3)}$. Uterine adenomatoid tumors, in particularly the intramural type, are often accompanied by smooth muscle hypertrophy, which is usually represented by an entrapped myometrium permeated by the adjacent tumor. In some cases, the prominence of smooth muscle component simulates a leiomyoma, thus the lesion is denoted as a 'leiomyoadenomatoid tumor'. The term "leiomyoadenomatoid" is a descriptive name for this lesion ${ }^{(4)}$. It reflects its histopathological appearance that is composed of prominent stromal smooth muscle proliferation accompanied by glandular structures. It is important for the surgeon and especially for the pathologist to recognize this tumor because; sometimes lesions with bizarre histological pattern could be misdiagnosed as malignant. We herein report a rare case of 30 year-old pregnant with leiomyoadenomatoid tumor at the left cornual end of the uterus.

\section{CASE REPORT}

A mass was detected at the left cornual end of the uterus in a 30 year-old woman in her 4. gestational month. Any uterine mass was not detected on her previous examinations. During follow-up period, the mass enlarged with time which was clinically accepted as a leiomyoma. During caesarean section, paratubal mass was found attached to the left ovary. This paratubal mass could be easily separated from the uterus, fallopian tube, and the ovary. Nodular mass was considered as a leiomyoma. It was removed delicately to preserve left ovary. A specimen of the mass was sent for histopathological examination.
Grossly, this white-coloured solid tumoral mass measuring $4.5 \times 4 \times 3 \mathrm{~cm}$ in size had a well circumscribed, smooth surface. The cut surface of the specimen showed solid, grey white mass with a whorled appearance (Figure 1).

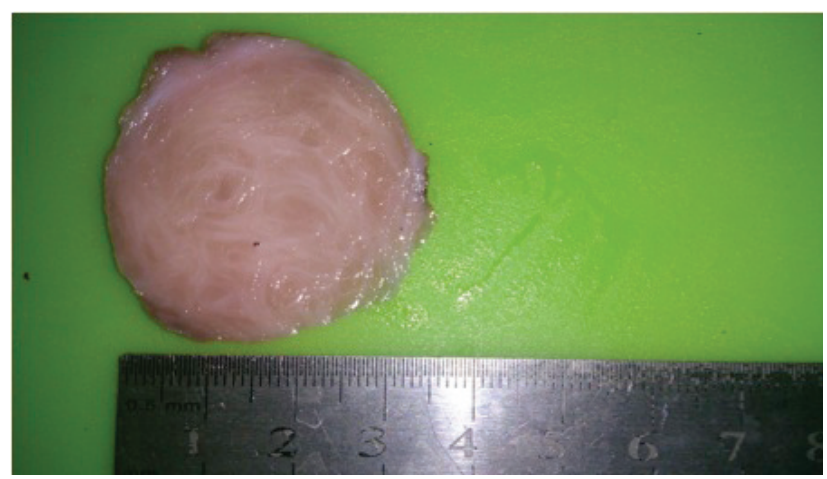

Figure 1. The cut surface of specimen showed solid, grey white mass with a whorled appearance

During the microscopic examination of the mass, prominent fascicles of smooth muscle were infiltrated by cuboidal to flattened and signet ringlike vacuolated epithelial-like cells and tubuloglandular cystically dilated spaces were observed, as well. (Figure 2a). Many small cystic spaces lined with low cuboidal cells were present (Figure 2b). Sometimes the lining cells were flattened. Mitotic activity, pleomorphism, nuclear hyperchromatism and stromal desmoplastic response were notably absent. A pseudocapsule composed of compressed smooth muscle fibers was present.

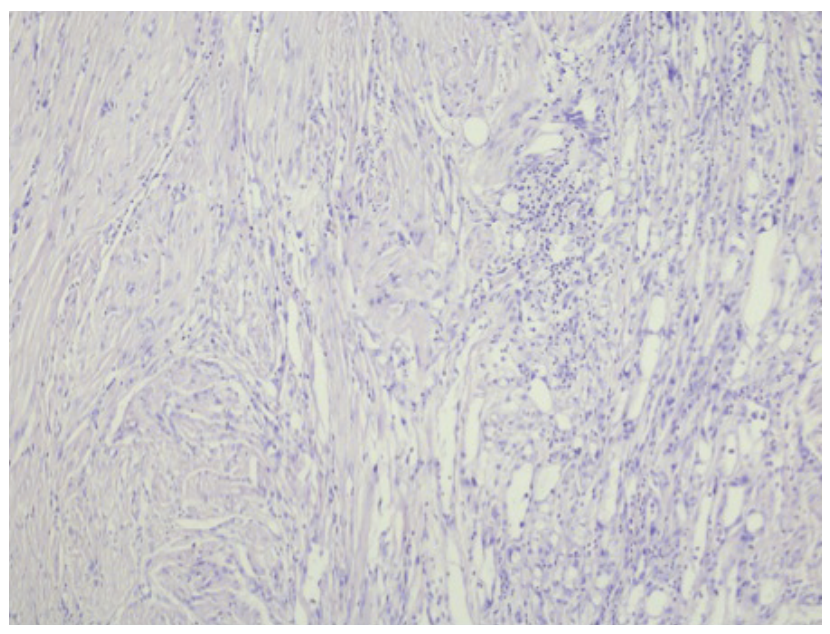

Figure 2a. Tubular-glandular cystically dilated formations along with prominent fascicles of smooth muscle (H\&E x100). 


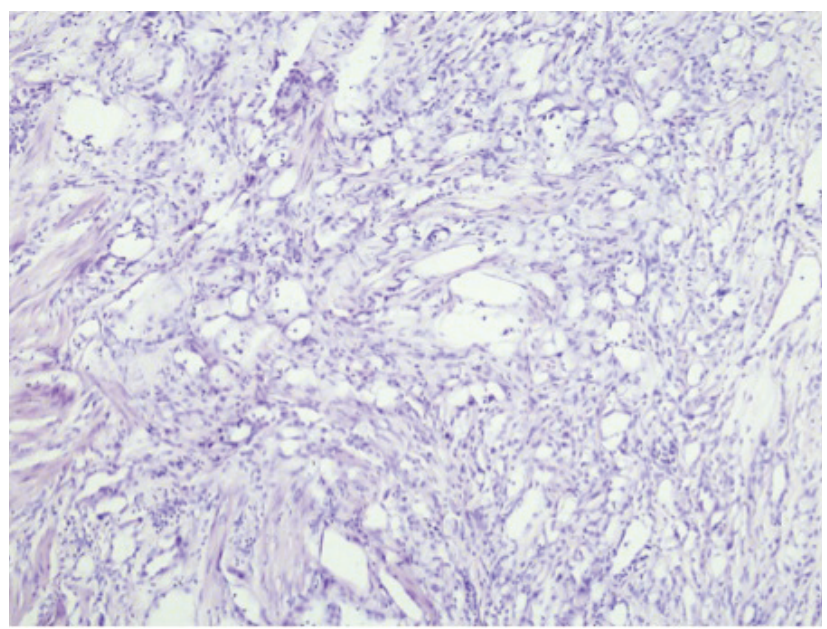

Figure 2b. Cuboidal to flattened and signet ring-like vacuolated epithelial-like cells in tubular-glandular formations (H\&E x200).

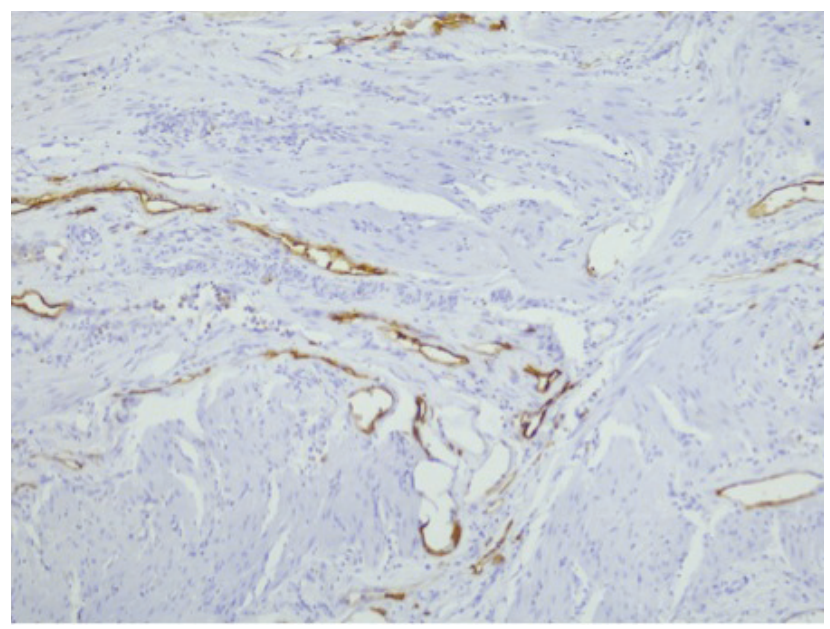

Figure 3a. Immunohistochemical stains for calretinin are diffusely positive in epithelial-like cells (calretinin x100).

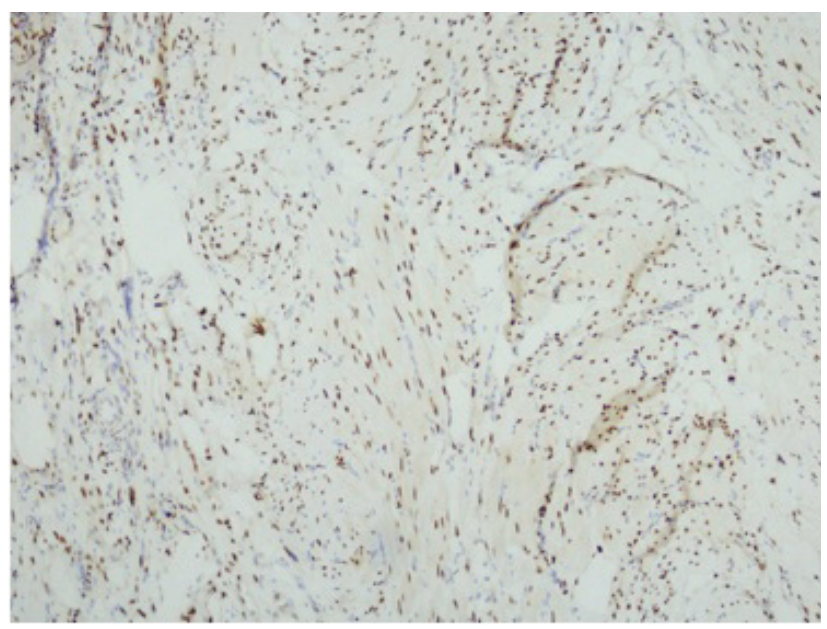

Figure 3c. Immunohistochemical stains for progesterone are diffusely positive in epithelial-like cells (calretinin x100).
In immunohistochemical analysis, epitheliallike cells were strongly positive for cytokeratin (CK), CK 7, EMA, HMBE-1, calretinin, progesterone (Figure $3 \mathrm{a}, \mathrm{b}, \mathrm{c}$ ). CK20, actin, caldesmon, CD34, CD31, and factor VIII-related antigen (FVIII), while D2-40 and CEA were negative. Fascicles of prominent spindle cells were positive for smooth muscle actin (Figure 3d).

The lesion was diagnosed as "leiomyoadenomatoid tumor".

Eight months after surgery, our patient is still asymptomatic and there is no evidence of recurrence.

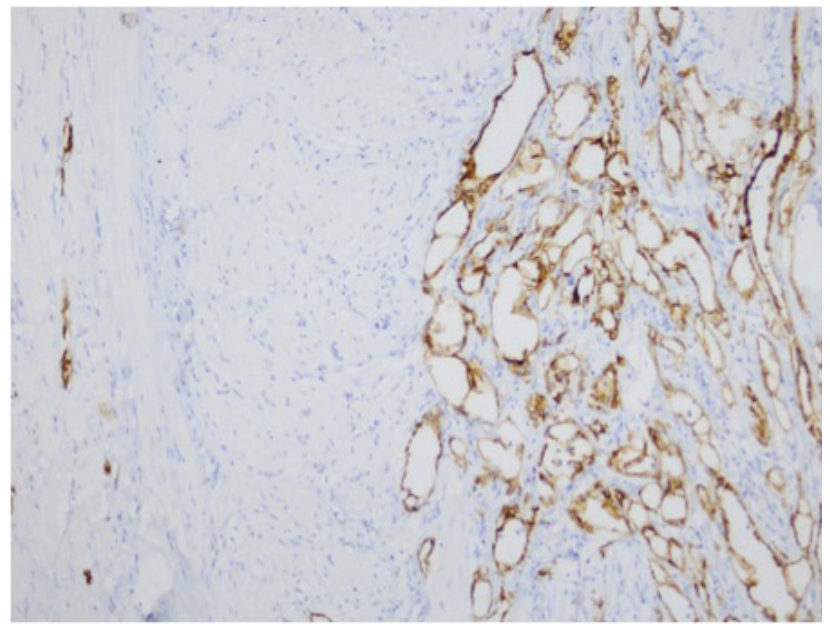

Figure 3b. Immunohistochemical stains for HMBE1 were diffusely positive in epithelial-like cells (HMBE1 x100).

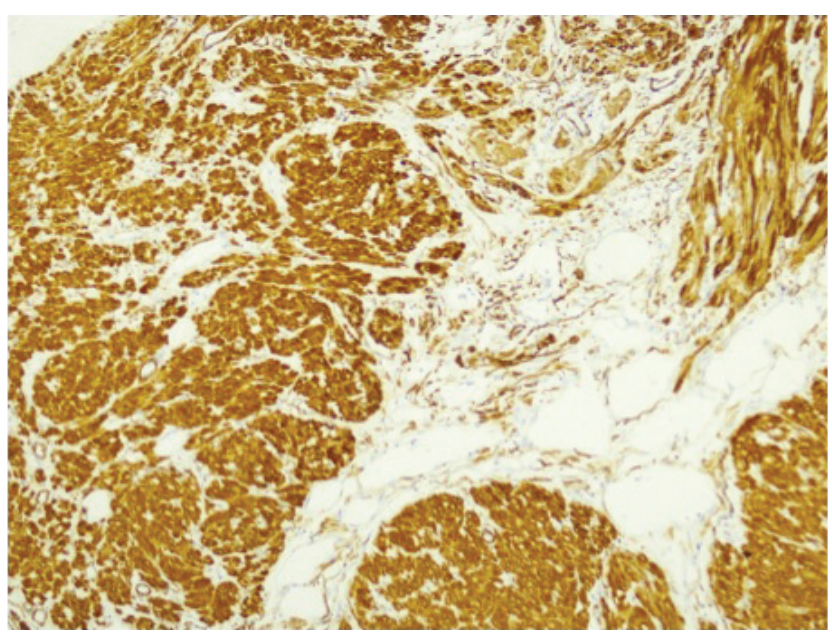

Figure 3d. Immunohistochemical stains for smooth muscle actin were diffusely positive in spindle cell bundles (SMAx200). 


\section{DISCUSSION}

The majority of adenomatoid tumors are readily diagnosed based on location and characteristic microscopic features ${ }^{(1-3)}$. However, various issues may cause diagnostic difficulties. For example, as in our case, an adenomatoid tumor with a dominancy of smooth muscle component may be mistaken for a leiomyoma. More importantly, tumors with a solid growth pattern or cords of cells can be mistaken for an infiltrating malignant epithelial or mesothelial neoplasm. Those with small vacuoles can be confused with a signet ring cell adenocarcinoma. Histologically, although these tumors can have an adenoid, angiomatoid, solid or cystic architecture, a mixture of these patterns is often seen in adenomatoid tumors, rather than adenocarcinomas. Also the complete absence of mitotic activity, cellular and nuclear pleomorphism should help to distinguish this tumor from adenocarcinoma. In our case, there was no mitotic activity, cellular and nuclear pleomorphisms. Tumor cells are strongly positive for cytokeratin, vimentin, calretinin and HBME-1 (antihuman mesothelioma antibody), but they do not express EMA, CE.

The term "leiomyoadenomatoid tumor" was first described by Epstein in 1992 as a variant of adenomatoid tumor with a prominent smooth muscle component ${ }^{(4)}$. Extensive smooth muscle overgrowth may sometimes obscure the adenomatoid tumor and result in a misdiagnosis of leiomyoma or more importantly malignant tumor infiltrating the smooth muscle bundles ${ }^{(5,6)}$. Cases of adenomatoid tumors in the uterus have been reported in the literature ${ }^{(1,3,5-7)}$. However, although extensive literature search was done by us, we didn't find any case with a leiomyoadenomatoid tumor which enlarged with time after detection in pregnancy. In our case the tumor was immunoreactive for progestrone but negative for oestrogen. Besides, it enlarged during pregnancy. For that reason we investigated the possibility of a relationship between pregnancy and the development of a leio- myoadenomatoid tumor. As has been reported in the literature, estrogen is considered to be the primary growth promoter of fibroids and there is also convincing evidence that the maintenance and growth of these lesions are progesterone dependent. However it is also noteworthy that selective progesterone-receptor modulators have been shown to effectively shrink fibroid size ${ }^{(8,9)}$. We suggest that pathophysiology involved in the growth of leiomyoadenomatoid tumors may be progesterone dependent like fibroids ${ }^{(10)}$. Sangoi et al reported that lymphoid aggregates were seen in all 12 adenomatoid tumors of male patients, but in only 4 of $32(13 \%)$ tumors in female patients. Lymphoid aggregates were infrequently (13\%) seen in the female genital tract and, when present they were focal lesions ${ }^{(7)}$. In our case, there was no lymphoid aggregates. Tumor cells positively express CK, calretinin, anti-human mesothelioma antibody (HBME-1). In our case, based on immunohistochemical analysis, expression of $\mathrm{CK}$ and calretinin was strongly positive. The histogenesis of the adenomatoid tumor was subject to debate, but it has been proven by ultrastructural and immunohistochemical studies to be a tumor of mesothelial origin. There are only six case reports in the English medical literature about uterine adenomatoid tumors which had been surgically removed (5,6,11-14). Our findings have documented the first example of leiomyoadenomatoid tumor detected in pregnancy in the literature.

We would like to report an additional case of this rare tumor because of its immunohistocemically estrogen negative and progesteron positive pathophysiology. But its pathophysiology must be supported with more case reports and large-scale studies.

We think that there is a possibility that a pathologist not familiar with this lesion may mistakenly diagnose this lesion as adenocarcinoma on the basis of its histologic appearance, Therefore awareness of this disease will result in a correct diagnosis. 
Acknowledgment: There was no pharmaceutical or industrial support for this case report.

\section{REFERENCES}

1. Sangoi AR, McKenney JK, Schwartz EJ, Rouse RV, Longacre TA. Adenomatoid tumors of the female and male genital tracts: a clinicopathological and immunohistochemical study of 44 cases. Mod Pathol 2009;22:1228-1235. http://dx.doi.org/10.1038/modpathol.2009.90

2. Perez-Ordonez B, Srigley JR. Mesothelial lesions of the paratesticular region. Semin Diagn Pathol 2000;17:294-306.

3. Bolat F, Kocer E, Bal N, Kucukgoz U. Adenomatoid tumor of the female genital tract: Report of three cases. Turk $J$ Pathol 2007;23:98-102.

4. Epstein JI. Urologic disorders: Differential Diagnosis in Pathology. New York, NY: Igasku-Shoin; 1992: 173-4.

5. Hong R, Choi DY, Choi SJ, Lim SC. Multicentric infarcted leiomyoadenomatoid tumor: a case report. Int J Clin Exp Pathol 2009;2:99-103.

6. Amre R, Constantino J, Lu S, Charney D. Pathologic quiz case: a 52-year-old woman with a uterine mass. Leiomyoadenomatoid tumor of the uterus. Arch Pathol Lab Med 2005; $129: 77-78$

7. Sangoi AR, McKenney JK, Schwartz EJ, et al. Adenomatoid tumors of the female and male genital tracts: a clinicopathological and immunohistochemical study of 44 cases. Modern
Pathology 2009;22:1228-1235.

doi:10.1038.

8. Ishikawa H, Ishi K, Serna VA, Kakazu R, Bulun SE, et al. Progesterone is essential for maintenance and growth of uterine leiomyoma. Endocrinology 2010;151:2433-2442. http://dx.doi.org/10.1210/en.2009-1225

9. Donnez J, Tatarchuk TF, Bouchard P, Puscasiu L, Zakharenko $\mathrm{NF}$, et al. Ulipristal acetate versus placebo for fibroid treatment before surgery. N Engl J Med 2012;366:409-420. http://dx.doi.org/10.1056/NEJMoa1103182

10. Nirmala D, Daya S. Uterine myomas revisited, European Journal of Obstetrics \& Gynecology and Reproductive Biology 2010;152:119-125. http://dx.doi.org/10.1016/j.ejogrb.2010.05.010

11. Erra S, Pastormerlo M, Gregori G, Costamagna D, Pavesi M. A case of leiomyoadenomatoid tumour of uterine serosa: speculations about differential diagnosis. BMJ Case Rep 2009; 2009.

pii: bcr02.2009.1586. http://dx.doi.org/10.1136/bcr.02.2009.1586

12. Amérigo J, Amérigo-Góngora M, Giménez-Pizarro A, Velasco FJ, Gallardo SP, González-Cámpora R. Leiomyoadenomatoid tumor of the uterus: a distinct morphological entity? Arch Gynecol Obstet. 2010;282(4):451-454. PMID: 0157717 http://dx.doi.org/10.1007/s00404-010-1383-7

13. Dobrosz Z, Paleń P, Właszczuk P, Stojko R. An atypical leiomyoadenomatoid tumor of the uterus--a case report and literature review. Ginekol Pol 2013;84(8):730-2. Review. 